\title{
Komunikasi pariwisata budaya dalam mempromosikan city branding "Siak the truly Malay"
}

\author{
Noor Efni Salam ${ }^{1}$, dan Nurjanah ${ }^{2}$ \\ ${ }^{1,2}$ Universitas Riau
}

\begin{abstract}
ABSTRAK
Kabupaten Siak dikenal dengan slogan Siak the Truly Malay, karena daerah ini merupakan wilayah berbasis budaya Melayu, bahkan sudah berhak memegang hak cipta atas branding Siak the Truly Malay, paten atas branding tersebut, menurut Kepala Bagian Humas Pemerintah Kabupaten Siak sudah terdaftar sejak 27 April 2017. Berdasarkan kenyataan itulah masyarakat Siak akhir-akhir ini bersemangat untuk mempromosikan city branding Siak the Truly Malay-nya. Tujuan penelitian ini adalah untuk menggali, menemukan, dan mendeskripsikankan berbagai promosi yang digalakan mereka terkait dengan wisata budaya ini. Metode penelitian bersifat kualitatif. Teknik pengumpulan data melalui wawancara mendalam, observasi dan dokumentasi. Hasil penelitian menunjukan bahwa komunikasi pariwisata yang dilakukan oleh masyarakat Siak,antara lain: memasarkan objek atau produk-produk budaya Melayu, baik situs-situs sejarah, kerajinan tradisional, kuliner dan kondisi geografis yang menunjang program tersebut sebagai brand Kabupaten ini, memberdayakan dan meningkatkan ekonomi kreatif yang mengarah kepada city creative; menyelenggarakan berbagai event budaya yang menjadi agenda tahunan, memaksimalkan berbagai saluran komunikasi, seperti situs-situs online, media elektronik, koran lokal dan berbagai publikasi lainnya, memperbaiki dan meningkatkan sarana dan prasana terutama infrastruktur dan elektrisasi, dan meningkatkan kerjasama dengan stakehlders. Beberapa rekomendasi untuk meningkatkan program ini, pemerintah sebaiknya memaksimalkan sarana dan prasarana di berbagai tempat wisata yang tengah dikembangkan; masyarakat ikut menjaga dan mengembangkan potensi ekonomi kreatif yang mereka miliki, stakeholder/Swasta seharusnya memberikan dukungan material secara maksimal terhadap program pemerintah dalam mempromosikan city branding ini.
\end{abstract}

Kata-kata Kunci: komunikasi pariwisata; budaya; city branding; promosi; Siak the truly Malay

\section{Cultural tourism communication in promoting the city branding "siak the truly Malay"}

\begin{abstract}
Siak Regency is also addressed with the slogan "Siak, the Truly Malay" because it was founded on the Malay Culture. It has also been able to claim copyright of this slogan since the 27th day of April 2017 when it was duly registered, propelling the community to promote it. Therefore, the purpose of this research is to explore, discover, and describe the promotional strategies employed by this community in promoting their cultural tourism. A qualitative research approach was adopted in this research and data were collected through indepth interviews, observation, and documentation. The results of this study showed that tourism conducted by the community, maintains and preserves Malay historical sites; empowers and raises creative economy, organizes various annual cultural events; maximizes multiple communication channels such as online sites, electronic media, local newspapers, and numerous other publications, fixes and improves facilities and infrastructures especially electricity, and increases cooperation among stakeholders. Some recommendations for improving this program, the government should maximize the facilities and infrastructure in various tourist attractions that are being developed, the community participates in maintaining and developing the creative economic potential they have,stakeholders / private sector should provide maximum material support for government programs in promoting city branding.
\end{abstract}

Keywords: Tourism communication; cultural; city branding; promoting; Siak the truly Malay

Korespondensi: Dr. Noor Efni Salam, M.Si, Universitas Riau, Kampus Bina Widya KM 12.5, Simpang Baru, Kec. Tampan, Kota Pekanbaru, Riau 28293, Email: noor.efni.salam@lecturer.unri.ac.id 


\section{PENDAHULUAN}

Siak Sri Indrapura merupakan salah satu kabupaten di Provinsi Riau yang memiliki situs-situs sejarah Melayu, kondisi ini dapat kita lihat dari sebuah Istana yang megah dan kokohnya hingga saat ini, yang dikenal dengan Istana Siak. Selain istana, kita masih menemui sebuah bangunan tempat raja-raja melakukan pertemuan dan perhelatan pada zamannya, yang dikenal dengan Balai Kerapatan Adat. Demikian juga makam raja-raja dan permaisurinya masih terjaga dan terawat dengan baik oleh masyarakat Siak.

Keberada Istana Siak ini merupakan salah satu simbol kebesaran bangsa Melayu yang mencerminkan tradisi kehidupan hampir sebagian masyarakat Indonesia. Oleh karena itu Kabupaten Siak yang memiliki potensi berbagai peninggalan sejarah dan budaya harus dilestarikan, dan masyarakatnya berkomitmen untuk membentuk heritage city yang berbasis wisata budaya Melayu.

Berangkat dari fakta sejarah tersebut, masyarakat Siak membuat slogan Siak the Truly Malay artinya jika masyarakat luas ingin mengetahui budaya Melayu yang sebenarmya, bisa mengunjungi Kabupaten Siak. Berbagai upaya telah dilakukan masyarakat Siak untuk mewujudkan "label" tersebut, baik dari penyelenggaraan event budaya, kerajinan tradisional, kuliner, dan berbagai aktivitas masyarakat yang berbasis kearifan lokal. Berdasarkan fakta ini juga Kabupaten Siak memang memiliki potensi wisata budaya Melayu yang layak dikembangkan agar dikenal dipenjuru dunia.

Potensi wisata budaya (Melayu) yang dimiliki Siak inilah yang mendorong masyarakatnya untuk membangun City Branding. City branding atau yang dikenal dengan pembentukan identitas kota, merupakan salah satu upaya agar Siak dikenal baik di tingkat nasional maupun internasional, dan pada tanggal 3 April 2017 yang lalu, Kabupaten Siak berhak memegang hak cipta atas branding Siak the Truly Malay, paten atas branding tersebut sudah terdaftar sejak Kamis (27/4/2017) dengan nomor pencatatan 01906, yang berlaku selama 50 tahun sejak ciptaan tersebut pertama kali diumumkan. Penetapan branding Siak The Truly Malay, seperti yang penulis kutip pada salah satu berita onlineyang mengatakan bahwa "Pemerintah Kabupaten Siak, Riau, resmi menjadi pemegang hak cipta atas branding "Siak Truly Malay, dan patennya terdaftar di Direktorat Hak Cipta dan Desain Industri Kementerian Hukum dan Hak Asasi Manusia”.

Banyak harapan yang digantungkan terhadap penghargaan yang diterima oleh masyarakatnya. Bupati Siak Syamsuar mengatakan dalam dalam laman yang sama 
bahwa "Siak the Truly Malay melekat sebagai representasi pariwisata di daerah berjulukan negeri Istana ini. Hak cipta berupa logo dan tagline itu diajukan ke Kemenkum dan HAM pada 3 April 2017, sementara Pemerintah Kabupaten Siak mulai mempopulerkannya sejak Maret 2013.

"dengan diterimanya hak cipta ini, Syamsuar berharap dapat menjadi motivasi bagi jajaran seluruh masyarakat Kabupaten Siak untuk bersama-sama memajukan dunia pariwisata".

\section{Di sisi lain Kepala Dinas Pariwista}

Pemeintah Kabupaten Siak mengatakan bahwa: "Pendaftaran logo dan tagline branding wisata tersebut, didasarkan pada ketentuan Undang-Undang Nomor 28 Tahun 2014 tentang perlindungan ciptaan di bidang ilmu pengetahuan, seni dan sastra." Begitu juga pernyataan yang disampaikan oleh Kepala Bagian Humasnya, yang mengatakan bahwa:

"dengan ditetapkannya status hak cipta tersebut, branding wisata Kabupaten Siak tidak bisa dijiplak daerah atau negara lain sehingga akan menjadi identitas daerah yang tengah giat mengembangkan industri tourism tersebut. Jadi hanya kita yang boleh pakai tagline dimaksud (Republika, co.id.Siak)."

Mengacu pada pernyataan di atas, maka jelas bahwa tujuan untuk membentuk city branding di Siak ini, selain menjadi identitas dan citra daerah sehingga akan diakui oleh berbagai pihak baik nasional maupun internasional, juga bertujuan untuk mengembangkan dunia pariwisata yang akan bermakna bagi target pasar. Seperti yang diungkapkan oleh Jannah bahwa city branding memiliki pengaruh signifikan terhadap keputusan berkunjung ke daerah tersebut, sehingga pariwisata budaya Kabupaten Siak akan dikenal di seluruh penjuru dunia (Jannah, 2014).

Untuk mencapai target ini dapat melakukan serangkaian promosi dengan memanfaatkan berbagai media promosi, antara lain membuat slogan yang yang menggambarkan brand ini, dengan demikian tentu saja dapat menarik calon investor yang ingin mengembangkan industrinya. Oleh karena itu masyarakat Siak harus bersama-sama dan bersinergi dalam mempromosikan Siak the Truly Malay sebagai branding di daerahnya, sehingga dapat meningkatkan pertumbuhan ekonomi dan kesejahteraan masyarakatnya. Hal ini disebabkan masyarakat Siak belum memiliki tingkat "sadar wisata" yang tinggi. Seperti yang disampaikan Efni menemukan bahwa keterlibatan dan tingkat kesadaran masyarakat (sadar wisata), dalam mengembangkan ekonomi kreatif yang dikelola Pemerintah Kabupaten Siak, belum terlihat dengan maksimal dalam bidang-bidang seperti kuliner, dan industri kerajian, dan sekelompok kecil masyarakat saja yang memanfaatkannya, sehingga belum menunjukkan peningkatan ekonomi lokal yang signifikan (Efni, 2016). Yuli menyebutkan 
bahwa kesuksesan dalam menjalankan destination branding tergantung bagaimana mencapai brand positioning dan brand identity yang unik dan berbeda dengan lainnya (Yuli, 2011). Oleh karena brand merupakan identitas dan representasi sebuah produk/kota (Putri, Sumartias, \& Sjoraida, 2018).

Berdasarkan latar belakang yang telah diuraikan diatas, maka yang menjadi perumusan masalah penelitian ini adalah "Bagaimana komunikasi pariwisata dalam mempromosikan Siak the Truly Malay sebagai city branding Kabupaten Siak Sri Indrapura?" dan yang menjadi tujuan peneitian untuk menggali dan menemukan bagaimana pemerintah Kabupaten Siak berupaya untuk mengungkapkan Siak the Truly Malay sebagai city branding dalam mengembangkan dunia pariwisata yang berujung pada penguatan ekonomi lokal. Secara rinci tujuan penelitiannya adalah, pertama, untuk menggali informasi tentang strategi yang dilakukan oleh masyarakat Siak dalam pembentukan city branding Kabupaten Siak; kedua, menggali informasi dalam mengembangkan strategi promosi yang dilakukan agar branding Siak the Truly Malay sehingga dikenal baik di tingkat nasional maupun internasional; ketiga, mendapatkan gambaran yang jelas dalam pengembangan dan target yang ingin dicapai pada industry tourism di Kabupaten Siak, dan mengungkapkan terkait dengan upaya pemerintah Kabupaten Siak untuk meningkatkan partisipasi masyarakat untuk pengembangan industry tourism.

Berikut ini beberapa teori dan konsep yang menjadi landasan pemikiran penelitian ini antara lain, tentang komunikasi pariwisata, city branding, dan siak the truly Malay. Komunikasi pariwisata adalah suatu aktivitas manusia dalam menyampaikan informasi tentang perjalanan ke suatu daerah maupun objek wisata yang akan dikunjungi wisatawan sambil menikmati perjalanan dari suatu objek wisata ke objek wisata lain, agar wisatawan tertarik dan sampai pada suatu tindakan untuk mengunjungi. Pariwisata budaya yang dimaksudkan dalam penelitian ini adalah wisata berbasis budaya. Jadi pariwisata budaya merupakan salah satu jenis pariwisata yang mengandalkan potensi kebudayaan sebagai daya tarik yang paling dominan sekaligus memberikan identitas bagi pengembangan wisata tersebut (Geriya, 1995).

Terdapat sepuluh elemen budaya yang menjadi daya tarik wisata yaitu, kerajinan, tradisi, sejarah dari suatu daerah, arsitektur, makanan lokal, seni dan musik, cara hidup suatu masyarakat, agama, bahasa, pakaian lokal/tradisional (Shaw, 1997). Jadi, pariwisata budaya merupakan aktivitas yang memungkinkan wisatawan mengetahui dan memperoleh pengalaman tentang perbedaan cara hidup orang lain, merefeksikan adat istiadatnya, 
tradisi religius dan ide-ide intelektual yang terkandung dalam warisan budaya yang belum dikenalnya (Nuryanti, 1996).

Perkembangan kepariwisataan sebenarnya sudah lama diatur oleh pemerintah, seperti yang terdapat pada TAP MPR No. IV/MPR/1978, yang menyebutkan bahwa pariwisata perlu ditingkatkan dan diperluas untuk meningkatkan penerimaan devisa, memperluas lapangan pekerjaan dan memperkenalkan kebudayaan. Pembinaan serta pengembangan pariwisata dilakukan dengan tetap memperhatikan terpeliharanya kebudayaan dan kepribadian lokal. Untuk itu perlu diambil langkah-langkah dan pengaturan-pengaturan yang lebih terarah berdasarkan kebijaksanaan yang terpadu, antara lain bidang promosi, penyediaan fasilitas serta mutu dan kelancaran pelayanan.

Jadi, jelas apa yang telah dinyatakan pada TAP MPR No. IV/MPR/1978 tersebut, bahwa pariwisata budaya juga merupakan peluang bisnis yang dapat mendongkrak penerimaan devisa daerah yang perlu dikembangkan dan dikelola dengan maksimal. Sebagaimana yang diungkapkan Wibawanto, 2015, dalam (Bakti, Sumartias, Damayanti, \& Nugraha, 2018) "pariwisata dianggap memiliki nilai ekonomi dalam pengembangan properti yang menghasilkan pendapatan yang cukup besar dan kemampuannya dalam menyediakan pekerjaan"

Untuk mengembangkan dunia pariwisata salah satu aspek yang paling penting diperhatikan adalah bagaimana mempromosikan potensi wisata budaya dengan berbagai strategi, karena pada dasarnya tujuan dari promosi pariwisata tidak lain adalah: 1). Memperkenalkan jasa-jasa dan produk yang dihasilkan industri pariwisata seluas mungkin. 2). Memberi kesan daya tarik sekuat mungkin dengan harapan agar orang akan banyak datang untuk berkunjung. 3). Menyampaikan pesan yang menarik dengan cara jujur untuk menciptakan harapan-harapan yang tinggi.

Selain komunikasi pariwisata budaya, konsep yang perlu ditampilkan dalam penelitian ini adalah city branding, karena berdasarkan konteks penelitian ini menjelaskan potensi budaya merupakan pembentukan city branding Kabupaten Siak yang layak dipromosikan dikembangkan melalui komunikasi pariwisata budaya. City branding adalah proses atau usaha membentuk merek dari suatu kota untuk mempermudah pemilik kota tersebut untuk memperkenalkan kotanya kepada target pasar (investor, tourist, talent, event) (Fajrini, Bakti, \& Novianti, 2018), (Kavaratzis, 2004) menjelaskan bahwa konsep city branding itu didasarkan pada pemahaman bahwa kota menyerupai sebuah institusi tertentu karena kompleksitas identitas yang ada di dalamnya, beserta berbagai stakeholder dan tanggung jawab serta aturan-aturan sosial di 
dalamnya. Oleh karena itu, sebuah kota bisa dikembangkan dan dipromosikan selayaknya sebuah institusi atau perusahaan tertentu. Seperti halnya produk yang dipasarkan dengan brand tertentu, berbagai aspek sebuah kota juga bisa dipasarkan demikian. Misalnya, kota bisa dipromosikan sebagai tempat untuk tinggal, bekerja atau destinasi yang layak dikunjungi dan bahkan tempat untuk berinvestasi (Kavaratzis \& Ashworth, 2005). Jadi, city branding merupakan pembentukan sebuah identitas yang sangat diperlukan untuk menarik wisatawan dan investor (Luthfi \& Widyaningrat, 2013)

Selanjutnya Kavaratzis, menyebutkan bahwa terdapat tiga tipe dari city branding, yakni pertama, menamai lokasi geografis sebagai nama brand, kedua, melakukan branding terhadap tempat dan juga produk yang dihasilkannya, dan ketiga, menamai tempat itu semata-mata seperti tempat pada umumnya (Kavaratzis, 2008). Dalam kaitannya dengan tipe-tipe ini, terdapat dua strategi city branding yang perlu ditekankan karena dalam masa kontemporer ini menjadi cukup populer, yakni penciptaan creative city dan experience city.

City branding merupakan suatubentuk upaya untuk membentuk citra dan makna dalam benak target pasar mengenai sebuah kota. Melalui citra yang ingin dibentuk tersebut, sebuah kota dapat menarik calon investor dan turis untuk datang berkunjung. Branding yang tengah dibentuk dapat memanfaatkan media promosi seperti membuat sebuah slogan, atau ikon yang mewakili dan menggambarkan brand kota sehingga upaya strategi branding tersebut sehingga membuat suatu kota mampu "berbicara" dengan stakeholder" (Larasati, 2016).

Dengan demikian city branding merupakan upaya pengembangan kota dari para perencana dan perancang kota beserta semua stakeholders (pemangku kepentingan). Seperti produk, jasa dan organisasi, kota sangat membutuhkan citra yang kuat dan berbeda dengan citra kota lainnya demi mengatasi persaingan untuk memperebutkan sumber daya ekonomi di tingkat lokal, regional, nasional maupun global. Melalui branding, sebuah kota mampu membangun ruh kota yang dapat ditunjukkan melalui infrastruktur kota untuk menarik wisatawan. Jadi, city branding yang dilakukan secara utuh merupakan salah satu upaya untuk meningkatkan perkembangan kota dan pariwaisatayang berujung pada peningkatan pendapatan asli daerah (Hilman, Megantari, 2018).

Siak the truly Malay merupakan identitas masyarakat Siak. Pesan yang ingin disampaikan pada slogan ini, bahwa jika wisatawan atau siapapun yang ingin mengetahui, mempelajari/ mengkaji dan meneliti tentang Melayu datanglah ke Siak, karena yang sebenarnya 
Melayu ada di Siak Provinsi Riau. Khususnya Kabupaten Siak budaya Melayu merupakan payung negeri, yang disandingkan dengan agama (Islam), oleh karena itu perlu dijunjung tinggi oleh semua pihak untuk menjaga perdamaian yang selama ini sudah terwujud. Sebuah fakta yang menandai perjalanan sejarah Siak sebagai pusat kebudayaan Melayu, kini tengah menggaungkan Siak the Truly Malay yang menjiwai grand design pengembangan budaya Melayu di Kabupaten Siak. Arah visioner mewujudkan Kabupaten Siak sebagai pusat kebudayaan Melayu di Indonesia tahun 2025, adalah dengan meningkatkan pelibatan masyarakat untuk secara bersama menggali, membangun, dan mengembangkan kampungkampung lama Melayu, demikian pula dengan kampung suku asli (Sakai dan Akit). Kuatnya akar budaya Melayu tidak sekedar menopang kehidupan masyarakat, tetapi menjadi penguat karakter bangsa untuk menyikapi intervensi budaya asing yang tidak sesuai dengan kepribadian bangsa. Pelibatan masyarakat sebagai pendukung kebudayaan melayu menjadi sangat penting.

Berbicara Siak the truly Malay, dapat ditelusuri dari sejarah keberadaan Kabupaten Siak itu sendiri. Berawal dari sebuah kerajaan yang berdiri tahun 1723 dengan raja pertama Raja Kecil bergelar Sultan Abdul Jalil Rahmat Syah. Bekas-bekas kerajaan ini, antara lain ditandai adanya bangunan Istana Siak yang berwarna kuning gading yang di dalamnya masih tersimpan berbagai macam benda koleksi kerajaan sebagai peninggalan sejarah. Perpaduan tiga gaya arsitektur Eropa, Arab, dan Cina terlihat nyata dari berbagai elemen bangunan dan ornamennya. Tatkala raja terakhir, Sultan Syarif Khasim II menyerahkan istana Siak sebagai aset nasional kepada Pemerintah Republik Indonesia sebelum akhir khayatnya, maka istana Siak yang berdiri megah itu pun, semakin kuat memiliki simbol payung negeri Melayu di Indonesia.

Jadi berdasarkan latar belakang sejarah sebagaimana yang telah diuraikan sebelumnya, fokus penelitian ini adalah untuk memotivasi masyarakatnya terutama pemangku kepentingan berupaya untuk mempertahankan, mengembangkan dan melestarikan budaya Melayu, sebagai salah satu kebudayaan nasional yang harus dijaga sekaligus menjadi destinasi wisata budaya yang layak dikembangkan sesuai dengan TAP MPR No. IV/MPR/1978. Hal ini telah dirumuskan dan tertuang dalam visi dan misi Kabupaten Siak.

Visi dan misi Kabupaten Siak, adalah ingin mewujudkan masyarakat Siak yang sehat, cerdas dan sejahtera dalam lingkungan masyarakat yang agamis dan berbudaya Melayu serta mewujudkan pelayaan publik terbaik, visi ini menekankan beberapa program 
yang sudah dan sedang dilaksanakan, yang menyadari potensi Siak yang kaya akan nilainilai tradisi, sejarah, dan budaya, pemerintah telah mengusulkan daerah ini sebagai kawasan heritage city atau kota yang memiliki kekayaan budaya dan sejarah yang harus dilestarikan.

Sejauh ini promosi Siak the truly Malay sebagai branding Kabupaten Siak belum dianalisis secara tajam. Penelitian ini berupaya mengkaji dan menganalisis tentang Siak berbasis budaya Melayu sebagai branding kota ini berdasarkan konsep-konsep yang telah dirumuskan sebelumnya.

\section{METODE PENELITIAN}

Penelitian ini dilakukan di Kabupaten Siak Sri Indrapura Provinsi Riau. Dilakukan pada bulan April-November 2018. Subjek atau informan penelitian ini adalah orang-oang yang terkait langsung dalam mengelola pariwisata budaya di Kabupaten Siak, seprti: Bupati, Ketua DPRD dan Anggota DPRD yang terkait, Pejabat pada Kantor Dinas Pariwisata, Dinas Perinustrian dan Perdagangan dan masyarakat lainya. Penentuan informan dilakukan secara purposive, dengan menentukan kriteria tertentu. Sedangkan objek dalam penelitian ini adalah komponen-komponen yang terkait dengan upaya Pemerintah Kabupaten Siak dalam membentuk city branding berbasis budaya Melayu (Riau), antara lain, merevitalisasi situs- situs sejarah, event budaya, kesenian, kuliner, kerajianan tradisional, dan perilaku masyarakat yang mencerminkan iai-nilai budaya Melayu.

Jenis data dalam penelitian ini ada 2 (dua) jenis yaitu data primer dan data sekunder. Data primer data yang diperoleh langsung dari informan berupa hasil wawancara langsung dengan pihak-pihak terkat dan observasi terhadap objek-objek penelitian. Sedangkan data sekunder didapatkan dari sumber-sumber yang terkait dengan penelitian ini, berupa dokumen-dokumen baik dalam bentuk jurnal, buletin, dan pemberitaan-pemberitaan melaui media cetak maupun online yang telah tersedia.

Teknik pengumpulan data dilakukan dengan teknik wawancara mendalam kepada pihak-pihak yang terkait seperti pengambil keputusan, dinas-dinas terkait, tokoh budaya, dan masyarakat lokal secara purposive. Di samping itu juga dilakukan wawancara mendalam terhadap pengunjung baik lokal, nasional/internasional secara accidental.Selain itu, dilakukan juga observasi terhadap objek yang diteliti untuk melengkapi informasi yang dibutuhkan peneliti seperti penggunaan media online terutama website. web site menurut Hardyantoro mencerminkan sisi emosional dan makna dari grafis website mengenai kota tersebut, dan menyelenggarakan Focus Group Discussion (FGD), serta mengumpulkan dokumentasi-dokumentasi terkait dengan 
penelitian (Hardyantoro, 2012).

Teknik analisis data dilakukan melalui beberapa tahap.Pertama, setelah mengumpulkan berbagai informasi (hasil wawancara, hasil observasi, dan dokumen-dokumen terkait) dilakukan reduksi sesuai degan kebutuhan penelitian. Setelah informasi tersaring sesuai dengan kebutuhan yang diharapkan maka dilakukan proses pemaknaan dan analisis sehingga dapat ditarik kesimpulan akhir.

\section{HASIL DAN PEMBAHASAN}

City branding merupakan keseluruhan aksi untuk membangun citra positif atas sebuah kota dan mengomunikasikan aksi tersebut kepada berbagai kelompok yang menjadi sasaran melalui visual, naratif, event baik yang bersifat lokal dan internasional untuk mendapatkan keuntungan-keuntungan yang bisa dikompetisikan dengan kota lain (Kavaratzis, 2008). City branding memiliki berbagai tujuan, pertama, untuk peningkatan pertumbuhan ekonomi; kedua, untuk meningkatkan aspekaspek sosial budayanya demi bisa meningkatkan kualitas hidup warga setempat kota itu.

Berdasarkan pengertian di atas, maka yang tengah dilakukan Kabupaten Siak dalam mempromosikan pariwisata dan meningkatkan daya saing ekonomi lokal warganya demi pencapaian Siak the Trully Malay adalah sebuah upaya yang mengarah pada city branding.
Lebih lanjut lagi, seperti diungkap Kavaratzis, terdapat tiga tipe dari city branding, yakni, menamai lokasi geografis sebagai nama brand, melakukan branding terhadap tempat dan juga produk yang dihasilkannya, dan menamai tempat itu semata-mata seperti tempat pada umumnya. Dalam kaitannya dengan tipetipe ini, terdapat dua strategi city branding yang perlu ditekankan karena dalam masa kontemporer ini menjadi cukup populer, yakni penciptaan creative city dan experience city.

Pada kasus Siak, pemerintah melaksanakan program city branding yang menggabungkan berbagai tipe di atas. Penamaan Siak sebagai Trully Malay merujuk pada lokasi geografis Istana Siak sebagai salah satu kerajaan Melayu yang signifikan dalam sejarah. Tetapi nama itu juga merujuk pada berbagai produk budaya lokal yang ada di Siak. Melihat fakta tersebut, penelitian ini berusaha melihat potensi-potensi yang dimiliki Siak sebagai modal utama proses city branding dan upaya-upaya pemerintah yang telah dilakukan untuk mewujudkannya. Penelitian ini juga berusaha merumuskan strategi demi meningkatkan dan mengefektifkan program city branding Kabupaten Siak yang dilakukan oleh pemerintah tersebut, juga oleh masyarakat dan kerja sama di antara keduanya dalam rangka meningkatkan ekonomi lokal.

Stretegi atau upaya konkret yang dilakukan pemerintah, masyarakat, stakeholder, ataupun 
gabungan diantara mereka, sebagai agen yang aktif bergerak menjalankan program tersebut. Terakhir, bagian ini akan menelusuri sejauh mana keberhasilan dan kendala yang muncul dalam mewujudkan program tersebut untuk kemudian merumuskan beberapa strategi penanggulangannya yang dibutuhkan demi terwujudnya Kabupaten Siak sebagai The Trully Malay.

Upaya untuk pencapaian brand Siak sebagai the trully Malay, mengacu pada visi rencana rembangunan jangka panjang daerah (RPJPD) tahun 2005-2025, yaitu terwujudnya Kabupaten Siak yang maju dan sejahtera dalam lingkungan masyarakat yang agamis dan berbudaya Melayu serta menjadikan Kabupaten Siak sebagai tujuan Pariwisata di Sumatera.

Visi ini kemudian dijabarkan lagi dalam beberapa poin misi sebagai berikut: mewujudkan kualitas sumber daya manusia yang sehat, cerdas, berakhlak, beriman dan bertaqwa; mewujudkan pembangunan infrastruktur daerah yang merata, terutama kampung-kampung serta penerapan pembangunan yang berwawasan lingkungan; mewujudkan perekonomian daerah yang mandiri dan berdaya saing melalui pembangunan dan pengembangan sektor pertanian, perkebunan, perikanan, dan peternakan serta sektor-sektor produktif lainnya; mewujudkan destinasi wisata yang berdaya saing; mewujudkan tata kelola kepemerintahan yang baik dan bersih serta pelayanan publik yang prima.

Berdasarkan visi dan misi Kabupaten Siak di atas serta batasan yang diberikan, sebagaimana yang dikatakan Karavatzis sebelumnya bahwa branding Kabupaten Siak adalah sebagai kota budaya dan wisata yang identitasnya bersumber pada sejarah dan peradaban Melayu, yang dilestarikan dan dikembangkan oleh seluruh lapisan masyarakat, serta didukung oleh upaya peningkatan kualitas SDM dan pembangunan infrastruktur, peningkatan perekonomian melalui beberapa sektor termasuk pariwisata dengan kawalan pemerintahan yang bersih. Branding ini kemudian lebih dikenal dengan semboyan Siak The Trully Malay.

Seperti sudah diuraikan di atas, pariwisata merupakan aspek utama sebuah upaya city branding. Dalam kasus Siak, aspek tersebut terpusat pada pariwisata yang bersifat kultural Melayu. Berbagai situs sejarah yang dilestarikan dan dikembangkan sebagai objek wisata utama, ndustri kerajinan dan kulinernya juga sebagai pendukung mempromisikan city branding.

Beberapa wisata budaya Melayu yang signifikan disebut sebagai pilar city branding di Siak yang saat ini dipromosikan antara lain sebagai berikut: 1) Istana Siak. Istana ini adalah peninggalan Kesultanan Siak yang merupakan sebuah Kerajaan Islam terbesar di Riau pada abad 16 - 20. Istana Siak Ini di bangun oleh Sultan Syarif Hasyim Abdul Jalil 
Syaiffudin pada tahun 1889. Istana inilah yang dapat disebut sebagai identitas utama Siak dalam melaksanakan program city branding. Yang menarik, di istana ini terdapat alat musik klasik langka yang hanya ada dua di dunia, satu buah di Jerman dan satu di Siak. Alat musik yang bernama Komet ini bisa menjadi satu daya tarik dan potensi dalam program city branding terutama di ranah internasional.

2) Jembatan Tengku Agung Sultanah Latifah. Jembatan ini merupakan ikon baru destinasi wisata Kota Siak yang menghubungkan 2 daerah antara Kecamatan Mampura dan Kecamatan Siak Sri Indrapura di atas sungai Siak yang membentang luas sekitar 1,2 kilo meter. Sejak 2007 jembatan ini menjadi salah satu pintu masuk menuju Kabupaten Siak selain melalui jalur sungai. Nama jembatan Tengku Agung Sultanah Latifah ini berasal dari nama istri dari Sultan Syarif Qasim II. Penamaan jembatan ini yang disesuaikan dengan sejarah Kesultanan Siak merupakan contoh nyata upaya untuk mengintegrasikan objek atau situs wisata yang baru, yang tadinya netral, menjadi bagian dari sejarah dan branding kemelayuan Kabupaten Siak. 3) Balai Kerapatan Adat Siak. Balai yang dibangun pada tahun 1886 di masa pemerintahan Sultan Syarif Hasyim, Sultan Siak ke XI secara gotong royong ini dikenal karena gaya arsitekturnya yang khas Melayu. Namun potensi yang ada sebenarnya lebih tampak pada wacana sejarah dibalik fungsi bangunan ini pada masa dahulu kala. Sejarah pembangunan balai yang dilakukan secara gotong royong oleh penduduk yang mendalami wilayah Datuk Empat Suku, yaitu Datuk Suku Tanah Datar, Datuk Suku Pesisir, Datuk Suku Lima Puluh, dan Datuk Suku Kampar dan digunakan untuk penobatan para raja, tempat musyawarah oleh para petinggi kerajaan dan tempat persidangan merupakan simbol dari budaya politik dan kepemimpinan Melayu yang bisa menjadi poin penting lain program city branding Kabupaten Siak. 4) Makam Koto Tinggi. Situs inimerupakan kompleks pemakaman rajaraja Kesultanan Siak yang letaknya berada di sebelah timur Istana Siak. Fungsi kompleks ini hampir sama dengan situs wisata sebelumnya. 5) Masjid Raya Syahabuddin. Masjid yang dibangun pada tahun 1926 oleh Sultan Assayyidis Syarif Kasim Abdul Jalil Saefudin terletak 500 meter dari Istana Siak. Arsitektur masjid ini merupakan perpaduan gaya Timur Tengah dan Melayu. Kelebihan ini juga bisa menjadi daya tarik dan poin branding Siak di mancanegara. 6) Kapal Kato Kesultanan Siak. Kapal ini merupakan kapal besi dengan bahan bakar batu bara yang dimiliki oleh Sultan Siak Sebagai kendaraan untuk mengunjung daerahdaerah kekuasaan Kerajaan Siak pada masa itu. 7) Benteng Tangsi Belanda. Kompleks benteng yang tinggal tersisa dinding tanpa atap pintu 
atau jendela ini salah satu peninggalan penting terkait hubungan Siak dengan bangsa asing pada masa itu. Sangat disayangkan pemerintah belum memiliki inisiatif memperbaiki satu situs penting yang mendukung program city branding.

Selain situs budaya yang sebagian besar merupakan kompleks arsitektural, beberapa wisata alam ada di Siak dan dikembangkan sebagai bagian dari identitas dan branding kota Siak, yang sekaligus dan terutama bisa mendatangkan manfaat bagi masyarakat sekitar. Misalnya, terdapat beberapa taman di Siak yang berpontensi dan cukup menarik dicermati seperti Taman Hutan Raya Sultan Syarif Kasim; Ekowisata Mangrove Mengkapan; taman serta bentang alam di sekitar Sungai Siak dan Sungai Tasik, seperti Taman Air Mancur Zapin di tepi Sungai Siak dan Turap di pinggir Sungai Siak; Taman Wisata Danau Zamrud; dan Susur Sungai Menpura.

Selain situs sejarah dan bentang alam, Siak juga memiliki produk kerajinan dan kuliner unggulan yang mendukung program city branding ini. Produk tersebut antara lain: 1) Produk Kerajinan/Kriya: tenun Siak, batik Siak, sulaman tekat, tanjak, gasing, anyaman strapping, anyaman lidi sawit, anyaman pandan dan kaos siak. 2) Produk Kuliner: kue bangkit, dodol siak, rengginang ubi, bolu kemojo, produk olahan nanas, dan sebagainya.
Semua aspek di atas merupakan potensi yang perlu dan tengah terus-menerus ditingkatkan melalui berbagai program, yang juga terkait dan berujung pada pemberdayaan ekonomi masyarakat Siak yang menjadi aspek utama keberhasilan sebuah city branding. Untuk mendukung semua itu, sampai sekarang, pemerintah sudah menyediakan dan terus meningkatkan pembangunan infrastruktur yang mendukung city branding Kabupaten Siak. Upaya itu tampak pada kondisi jalan sebagai akses ke ibukota Kabupaten yang sudah sangat baik, juga dengan kondisi jalan sebagai akses ke area industri kreatif menengah masyarakat. Tingkat elektrifikasi di Kabupaten Siak juga telah tinggi seiring dengan berkembangnya kota dalam bidang wisata secara umum perkembangan jasa industri perhotelan, terbangunnya spot pariwisata (buatan) yang baru, dan tersedianya pusat pemasaran produk IKM yang difasilitas pemerintahan Kabupaten Siak sendiri.

Beberapa strategi yang dilakukan pemerintah, masyarakat dan stakeholders dalam mempromosikan city branding memiliki konsep bahwa city branding merupakan proses pembentukan personality atau karakter sebuah kota demi memenuhi berbagai fungsinya untuk masyarakat. Fungsi ini haruslah kuat dan distingtif dengan cara menawarkan produk yang superior (Pfefferkorn, 2005). Dari 
penjelasan ini, dapat diketahui bahwa sasaran utama city branding adalah masyarakat yang mendiaminya, bagaimana identitas sebuah kota berfungsi, diterima dan mendatangkan banyak manfaat bagi masyarakat. Oleh sebab itu, tujuan utama mengupayakan city branding adalah untuk meningkatkan turisme, menarik investasi, juga untuk menggapai perkembangan kota urban, mendukung regenerasi dan peningkatan kualitas hidup (Dinnie, 2011). Selanjutnya, city branding didukung oleh konsep-konsep turunannya seperti penciptaan creative city, yang diharapkan bisa menarik masyarakat menjadi lebih kreatif dalam rangka meningkatkan ekonomi lokal (Florida, 2003). Konsep lain yang juga sangat vital adalah urban planning, dan pendekatan menyeluruh yang mendukungnya (Scott, 2006). Kemudian, tiang penyangga utama dalam city branding adalah vibrant culture life di mana tujuan utamanya sekaligus untuk membangkitkan kembali (revive) dan mempertahankan kehidupan berbudaya masyarakatnya (Peel \& Lloyd, 2008).

Berdasarkan kerangka konseptual di atas, maka upaya city branding Kabupaten Siak dimulai dengan visi misi yang berpusat pada kebangkitan dan pemertahanan budaya Melayu sebagai pencipta vibrant culture life masyarakat yang mendiaminya. Kemudian, visi misi itu dicapai dengan urban planning yang komprehensif meliputi peningkatan pariwisata budaya dan alam dan peningkatan ekonomi lokal sehingga tercapai Siak sebagai kota kreatif Melayu (Creative Malay City).

Selain pembangunan berbagai tempat wisata baru di Siak, salah satu upaya yang masif dan sangat nyata terlihat dari pemerintah adalah integrasi event dan momen-momen kultural pada situs-situs wisata tersebut di Siak. Contoh terbaiknya adalah yang dilakukan pemerintah terhadap Taman Air Mancur Zapin dan pembangunan turap di pesisir Sungai Siak. Daya tarik utama taman ini adalah tata permainan cahaya lampu yang membuat taman terlihat indah di malam hari. Belum lagi ditambah perpaduan dengan suara musik lagu Zapin Melayu. Air akan bergerak mengikuti irama lagu Zapin Berjoget ataupun juga irama komposisi Mozart yang diputar oleh petugas.

Taman Air mancur Zapin ini sekarang merupakan salah satu destinasi wisata di Siak yang baru dan banyak dibicarakan di media sosial. Selain menjadi tempat alternatif untuk wisata malam masyarakat Siak, taman ini juga mengupayakan untuk terus dan tetap mempromosikan budaya Melayu kepada masyarakatnya. Ada upaya integrasi dan kontekstualisasi Melayu pada aspek wisata populer kekinian yang bisa dinikmati oleh masyarakat Siak.

Selain Taman Air Mancur Zapin, 
pembangunan turap di sepanjang sungai Siak juga menarik untuk ditelurusi. Dalam dua tahun terakhir, Dinas Pekerjaan Umum (PU) Siak menyulap kawasan tepi sungai yang kumuh menjadi taman bunga. Di sepanjang turap itu, ada arena untuk bermain anak-anak dan warungwarung di tepi sungai yang menjajakan berbagai makanan. Bangunan turap akan semakin terlihat indah yang posisinya di depan kawasan Istana Siak. Menurut keterangan yang diperoleh dari Kepala Dinas PU Siak, Irving Kahar Arifin, Pemerintah Kabupaten Siak membangun turap yang megah untuk memanjakan warga yang ingin bersantai di tepi sungai Siak sembari melihat kapal-kapal tongkang pengangkut kayu melintas. Malam hari, bangunan turap akan tampak semakin menarik dengan kerlap-kerlip lampu hias yang memenuhinya.

"Sekarang tak hanya Istana Siak saja jadi tempat kunjungan warga. Malah sebagian besar menghabiskan waktunya di bangunan turap di tepi sungai. Apa lagi malam tahun baru, warga banyak membawa keluarganya menikmati pergantian tahun di tepi sungai Siak yang sudah kami bangun," kata Irving. Dan pembangunan Turap ini merupakan contoh paling jelas bagaimana masyarakat didekatkan pada budaya dan sejarahnya. Dengan demikian masyarakat difasilitasi sekaligus diedukasi untuk semakin memperkuat identitas kemelayuan mereka. Turap ini juga menjadi contoh bagi daerah lainnya yang ada di Riau, yang dengan demikian, secara otomatis, program city branding mulai berjalan.

Himbauan ini kemudian dikuatkan oleh berbagai event seni budaya melayu yang religius, yang dilaksanakan sebagai kegiatan rutin tahunan. Event atau festival-festival ini diharapkan mampu memperkenalkan kebudayaan melayu Siak agar branding Siak the Truly Malay semakin dikenal baik di tingkat nasional maupun internasional. Beberapa event yang penting dan signifikan antara lain adalah Festival Siak Bermadah, Festival Ghatib Beghanyut, Festival Kuliner Bubur Asyura, Serindit Boat Race dan Tour de Siak.

Festival Siak Bermadah yang menampilkan ragam seni budaya siak, misalnya tari zapin tradisi, senandung menidurkan anak, lawak, lagu melayu dan lain sebagainya. Sementara itu, Festival Ghatib Beghanyut menampilkan sisi kehidupan masyarakat melayu yang relijius, sama halnya dengan Festival Kuliner Bubur Asyura. Untuk Serindit Boat Race dan Tour de Siak, pemerintah Kabupaten Siak berupaya memadukan olahraga balap dan olahraga air dengan seni kebudayaan sebagai daya tarik wisata.

Event semacam Serindit Boat Race dan Tour de Siak merupakan ajang dimana integrasi dan kontekstualisasi Melayu bekerja di ranah internasional. Seperti yang diungkapkan oleh 
Aris Dharma, Kepala sub bagian Humas Pemerintah Kabupaten Siak, bahwa even di atas terus dipromosikan dan dipamerkan sebagai potensi pariwisata, juga diekspos terus menerus melalui media berupa konferensi pers serta pameran foto di tempat-tempat lain, misalnya di Ibu Kota Jakarta.

Selain upaya untuk mengkontekstualisasikan Melayu dengan pariwisata yang tengah populer, pemerintah juga berupaya maksimal pada peningkatan ekonomi lokal masyarakat, guna mewujudkan Siak sebagai Malay creative city. Pemerintah secara sinergis tidak hanya memfasilitasi eksibisi seni budaya tetapi juga pameran pembangunan dan ekonomi kreatif dalam setiap kesempatan pelaksanaan event apapun di Kabupaten Siak.

Dalam upaya itu, tentu saja masyarakat menjadi subjek utama penggerak dan pelaku branding Siak sebagai The Truly Malay, sementara pemerintah menjadi fasilitator dan penyandang dana, dengan stakeholder swasta sebagai pendukung dan sponsor dalam setiap pelaksanaan event tersebut.

Sebagai fasilitator dan penyandang dana dan demi mewujudkan Siak sebagai Malay creative city, pemerintah telah melakukan berbagai program dan kegiatan yang mendukung pengembangan industri kecil dan menengah Kabupaten Siak yang diselaraskan dengan RPJMD Kabupaten Siak yang secara eksplisit tertuang pada visi dan misi Kabupaten Siak. Bentuk program dan kegiatan tersebut antara lain: diversivikasi produk kerajinan, peningkatan mutu produk, pembinaan IKM dalam memperkuat kluster industri, dan sebagainya.

Pemerintah juga melakukan kerjasama peningkatan sumber daya manusia pelaku Industri Kreatif Masyarakt (IKM) Kabupaten Siak dengan tujuan peningkatan daya saing lokal, antara lain dalam bentuk: kerjasama dengan Balai Diklat Industri Padang Kementrian Perindustrian dalam rangka peningkatan SDM IKM bidang fashion, kerjasama Tripartit antara Pemerintah Kabupaten Siak, Riau Pulp \& Paper dan Universitas Riau dalam pengembangan produk lokal dan kerjasama dengan Bekraf dalam rangka fasilitasi Hak Kekayaan Intelektual.

Pemerintah juga telah menyediakan sarana pemasaran produk IKM Kabupaten Siak berupa penyediaan Pasar Seni Siak, penyediaan gerai pemasaran produk IKM Siak di hotel-hotel di Pekanbaru, serta sarana pemasaran yang bersifat online melalui sosial media serta kerja sama dengan Dinas Perindustrian Propinsi Riau.

Pemerintah juga memberikan peran yang sifatnya edukatif dalam rangka peningkatan partisipasi masyarakat untuk pengembangan industri turisme antara lain seperti yang sudah dicontohkan beberapa di atas, yakni melakukan 
event yang melibatkan partisipasi masyarakat secara langsung; melakukan sosialisasi langsung terhadap masyarakat dalam pengembangan industri turisme; dan melakukan pendampingan langsung di lapangan dalam rangka memotivasi dan mensupervisi perngembangan IKM terkait industri turisme.

Untuk program sosialisasi, bahkan pemerintah memiliki sasaran khusus seperti pemuda-pemudi di Siak untuk bisa memiliki kesadaran untuk merintis dan memajukan industri kreatif lokal. Hal ini disampaikan oleh bupati Siak pada seminar "Menjadi Pemuda Sukses Zaman Now" yang dihelat Desember tahun 2017 lalu. Bupati Siak Syamsuar mengatakan kegiatan seminar ini berguna untuk menyiapkan generasi muda mumpuni yang siap bersaing di dunia usaha dan kreatifitas. Kegiatan ini lanjutnya, memotivasi seseorang yang berhasil berusaha menjadi pengusaha dan menyesuaikan dengan situasi kondisi negara dan bangsa saat ini, bukan hanya bangsa Indonesia tapi juga dunia.

Selain pemerintah, masyarakat juga berperan aktif dan telah memberikan kontribusi besarnya dalam segala upaya yang termasuk ke dalam city branding, terutama pada aspek ekonomi kreatif. Bukti terkait peran aktif itu tampak cukup signifikan seperti berkembangnya spot pariwisata yang dibangun oleh kelompok swadaya masyarakat seperti ekoturisme
Mengkapan dan Taman Menara Bunga Raya.

Selain menawarkan keindahan kawasan yang menyuguhkan panorama pantai dan hamparan laut, kawasan ekowisata Mangrove ini juga menawarkan berbagai wisata edukasi tentang mangrove, mulai dari jenisnya, pembibitan, penanaman, dan sebagainya bagi para pengunjung. Di kawasan ini juga disediakan suatu area yang dinamakan "Gembok Cinta Mangrove". Biasanya para pengunjung yang datang ke sini memasang gembok dengan tujuan agar ikut serta mencintai Mangrove dan melestarikannya.

Biaya masuk ke kawasan wisata ini adalah gratis. Sementara itu, ke depannya pemerintah berencana untuk mengembangkan kawasan ini dengan menambah sarana dan prasananya seperti menyediakan sampan untuk menyusuri keindahan Mangrove dan menambah fasilitasfasilitas lain yang menunjang peningkatan jumlah pengunjung.

Cerita yang sama juga bisa didapatkan dari proses pembangunan Taman Menara Bungaraya. Pembangunan taman ini digagas pertama kali oleh Kelompok Sadar Wisata (Pokdarwis) Luansa Lestari di Kecamatan Bungaraya, Siak. Mereka bahkan kemudian menambah beberapa spot seperti menara untuk berfoto, taman bunga di seputar menara tersebut dan pendopo untuk menikmati suasana persawahan serta lokasi tempat makan minum dan kolam pancing. 
Untuk anak-anak disediakan wahana permainan air dan taman edukasi terkait berbagai macam tanaman palawija.

Pembangunan yang digagas oleh Pokdarwis Luansa Lestari ini mendapat dukungan pihak Pemerintahan Kampung Buantan Lestari bekerjasama dengan Pemerintah Kecamatan serta Kabupaten Siak. Yang menarik, agrowisata ini dibangun di atas sawah pribadi milik Hadno Alias Hendro. Pemilik sawah ini menyerahkan dan mendukung program pemerintah kampung dalam pembangunan agrowisata dan dirinya juga terus mengupayakan kerjasama dengan pemerintah untuk sama-sama mengembangkan agrowisata tersebut.

Secara lebih spesifik, peran masyarakat di dalam industri ekonomi kreatifdan hubungannya dengan turisme budaya Melayu tampak pula dalam cara mereka mempromosikan peradaban melayu yang berbentuk seni. Mereka membentuk sanggar budaya baik tari, musik, maupun teater, seperti Sanggar Seni Sultan Syarif Kasim dan Sanggar Seni Tari dan Musik Tasek Seminai; mereka juga menjadi pelaku usaha cinderamata dan kuliner dan menjadi duta wisata dengan berpartisipasi menjaga kebersihan kota dan kelestarian budaya dan lain sebagainya.

Salah satu contoh yang signifikan terkait peran masyarakat sebagai pelaku usaha tampak pada usaha Kelompok Wanita Tani (KWT) di kampung Tualang Timur, Kecamatan Tualang dalam membuat dan memasarkan kerajinan piring dan tempat buah dari lidi. Usaha kerajinan ini sudah merambah pasar internasional melalui sistem pemasaran online yang mereka buat. Selain konsumen yang terus bertambah, kelompok ini pun berkembang hingga kini sudah terdapat 2 kelompok usaha.

Pihak ketiga yang perlu dipertimbangkan perannya dalam upaya city branding Kabupaten Siak selain pemerintah dan masyarakat tentu saja adalah pihak swasta. Selain di bidang wisata, swasta juga dan terutama dibutuhkan perannya dalam peningkatan ekonomi kreatif. Yang dilakukan oleh hotel-hotel dalam upaya ikut mempromosikan produk kerajinan lokal Siak kepada pengunjung merupakan salah satu bentuk peran serta swasta dalam bidang ekonomi kreatif. Namun yang dibutuhkan Siak dalam rangka city branding lebih dari peranperan tersebut. Pemerintah dan masyarakat Siak membutuhkan peran swasta yang lebih signifikan, yang bisa didapatkan melalui promosi dan penawaran-penawaran program yang baik. Dengan potensi yang maksimal, investasi dalam skala besar bisa didapatkan dari pihak swasta demi pengukuhan branding Siak sebagai masyarakat Melayu yang mandiri secara ekonomi.

Untuk mempromosi Program City Branding Kabupaten Siak, mereka memiliki 
situs resmi yang di dalamnya juga memuat informasi tentang pariwisata di Siak yaitu www. siak.go.id. Selain itu, terdapat sejumlah media online yang telah digandeng sebagai partner dalam mempromosikan pariwisata Siak dalam kurun waktu beberapa tahun terakhir, misalnya goriau.com, kompas.com, detik.com, republika. com, dan media lainnya dengan frekuensi promosi yang disesuaikan dengan kekuatan finansial daerah.

Secara lebih spesifik, pemerintah juga menggunakan media sosial dalam mempromosikan branding Siak the Truly Malay agar dapat dikenal baik di tingkat nasional maupun internasional, misalnya Fanpage dan instagram Pemkab Siak, laman Pariwisata Siak, instagram komunitas Siak Explore, akun Genpi Siak, akun youtube.com dan lain-lain. Seperti yang disampaikan Budiarjo bahwa untuk memasarkan priduk wisata masyarakat tidak perlu menghabiskan dana dalam menyelenggarakan pameran dan lain-lain, tapi cukup menggunakan media ini yang jauh lebih murah (Budiarjo, 2017).

Berbagai media sosial ini dimanfaatkan sebagai channel diseminasi pesan visual, dalam arti yang lain, sebagai sarana eksibisi dokumentasi pariwisata. Pengelolaan akun ini dilakukan secara resmi oleh pemerintah daerah dan didukung relawan duta wisata genpi dan komunitas misalnya penggiat fotografi Siak
Explore. Selain menggunakan media online, pemerintahan Siak juga melakukan promosi melalui media konvensional. Setiap event wisata yang dilaksanakan oleh Pemerintah Siak akan disebarluaskan oleh media cetak dan elektronik yang bermitra dengan Pemkab Siak, misalnya melalui laman advetorial, infotorial, galeri foto, maupun pemberitaan kegiatan pra dan pasca event wisata.

Strategi komunikasi di atas juga dibarengi dengan promosi kegiatan dengan cara mengirim kelompok-kelompok seni budaya dari Siak sebagai kontingen dalam festival-festival baik nasional maupun internasional. Juga dengan mengikutkan produk-produk IKM dalam berbagai pameran ekonomi kreatif di berbagai wilayah dalam dan luar negeri.

\section{SIMPULAN}

Program city branding "Siak the trulyy Malay" yang dipromosikan oleh Kabupaten Siak Sri Indrapura Provinsi Riau, dilakukan dengan memasarkan objek atau produk-produk budaya Melayu, baik situs-situs sejarah, kerajinan tradisional, kuliner dan kondisi geografis yang menunjang program tersebut sebagai brand Kabupaten ini. Untuk mewujudkan Siak the Trully Malay, pemerintah Siak terus menggenjot dan mengutamakan pengembangan wisata budaya dan sejarah, juga wisata hiburan populer untuk masyarakat yang tetap dikontekskan 
dengan budaya Melayu. Bahkan beberapa situs wisata baru telah dibangun baik oleh pemerintah maupun masyarakat dan atau kerjasama keduanya dengan pihak swasta untuk semakin menyukseskan program tersebut. Namun, bisa dikatakan program ini masih jauh dari sempurna mengingat secara teknis beberapa tempat wisata masih dalam proses pembangunan dan berbagai fasilitas masih belum dilengkapi.

Secara bersamaan, pemerintah juga terus memperbaiki sarana dan prasana terutama infrastruktur dan elektrisasi, yang selain mendukung keberadaan sektor pariwisata, juga mendukung pengembangan aspek ekonomi kreatif lokal yang menjadi tonggak lain perwujudan city branding Kabupaten Siak. Kemandirian pada aspek ekonomi kreatif ini, dengan dukungan penuh dari pemerintah dan swasta, bisa mengarahkan Siak pada pencapaian sebuah creative city. Dalam hal ini, beberapa aspek masih perlu ditingkatkan seperti masuknya investor dan kerjasama dengan pihak swasta. Juga dengan peningkatan kualitas produk itu sendiri yang sempat menjadi perhatian bupati Siak secara langsung.

Dalam aspek promosi, pemerintah telah mengandalkan berbagai jenis media untuk mendukung program tersebut. Walaupun demikian, aktivitas mempromosikan dalam mengkomunikasikan masih perlu ditingkatkan lagi. Berdasarkan penelusuran yang dilakukan peneliti, situs-situs online milik pemerintah tidak di-update konten dan beritanya. Selain itu, informasi yang ada pun terbatas dengan menggunakan bahasa yang formal. Jika dibandingkan dengan situs-situs milik institusi lain, atau bahkan milik pribadi-pribadi, situs pemerintah masih kurang progresif. Untuk meminimalisasi berbagai kekurangan yang ditemukan dan menjadi kendala tercapainya Siak sebagai The Trully Malay, peneliti merangkum beberapa saran sebagai berikut: Bersamaan dengan pelengkapan terhadap infrastruktur, pemerintah harus terus memaksimalkan sarana dan prasarana di berbagai tempat wisata yang tengah dikembangkan. Pemerintah juga perlu memfasilitasi masyarakat untuk berperan aktif mendukung program city branding baik sebagai pemeluk budaya Melayu maupun sebagai pelaku IKM. Masyarakat perlu menjadi pihak yang paling aktif dalam proses pembentukan city branding Siak melalui keikutsertaannya dalam setiap even budaya yang diselenggarakan pemerintah; ikut menjaga dan memanfaatkan tempat wisata baik budaya maupun alam sesuai dengan peran dan kebutuhannya; juga memanfaatkan layanan pemerintah dalam mengembangkan potensi ekonomi kreatif yang mereka miliki. Memberikan dukungan material secara maksimal terhadap program pemerintah yang ditujukan kepada masyarakat dan menjadi pihak yang secara aktif ikut mempromosikan 
dan menjadi pengguna utama berbagai produk ekonomi kreatif lokal. Melanjutkan penelitian terkait city branding di Kabupaten Siak pada waktu mendatang, dengan ruang lingkup dan perspektif yang berbeda demi menemukan rumusan-rumusan lain yang bisa dimanfaatkan oleh pemerintah Siak dalam menyusun kebijakan terkait program city branding tersebut

\section{DAFTAR PUSTAKA}

Bakti, I., Sumartias, S., Damayanti, T., \& Nugraha, R. (2018). Pengembangan model komunikasi pariwisata berbasis kearifan lokal di kawasan geopark Pangandaran development of local tourism based tourism communication model. Jurnal Kajian Komunikasi, 6(2), 217-230. Diambil dari http://jurnal.unpad.ac.id/jkk/article/ view/18459/9170

Budiarjo. (2017). Teknologi informasi dan komunikasi untuk pariwisata: analisa isi laman resmi pariwisata Provinsi Kepulauan Riau. Spirit Publik, 12(1).

Dinnie, K. (2011). City branding, theory and cases. New York: Palgrave McMillan.

Efni, N. (2016). Tata kelola event budaya dalam mempromosikan program siak the truly Malay sebagai penguatan ekonomi lokal dan revitalisasi budaya Melayu. Pekanbaru: Unri Press.

Fajrini, N., Bakti, I., \& Novianti, E. (2018). City branding Sawahlunto Kota wisata tambang yang berbudaya melalui event Sawahlunto international songket carnival (sisca) 2016 city branding Sawahlunto "the cultured coal mining tourism city" through the
Sawahlunto international songket carnival eve. PRofesi Humas: Jurnal Ilmiah Ilmu Hubungan Masyarakat, 2(2), 169-185. Diambil dari http://jurnal.unpad.ac.id/ profesi-humas/article/view/12861/7830

Florida, R. (2003). Cities and the Creative Class" in City \& Community: RAI, 2(1), 3-19.

Geriya, W. (1995). Pola partisipasi dan pemberdayaan sumber daya adat perkembangan pariwisata Denpasar. Denpasar: Upada Sastra.

Hardyantoro, S. (2012). Perean website sebagai penunjang city branding Yogyakarta. Jurnal Ilmu Komunikasi, 2(1).

Hilman, Yusuf Adam Megantari, K. (2018). Model city branding sebagai strategi pengauatan pariwisata lokal Jawa Timur. Jurnal Komunikasi dan Kajian Media, 2(2).

Jannah, B. (2014). Pengaruh city branding dan city image terhadap keputusan berkunjung wisatawan Banyuwangi. Jurnal Administrasi Bisnis (JAB), 17(1).

Kavaratzis, M. (2004). From city marketing to city branding: Towards a theoretical framework for developing city brands. place branding and public diplomacy, 1(1), $53-54$.

Kavaratzis, M. (2008). "From city marketing to city branding: aninterdisciplinary analysis with reference to Amsterdam, budapest and athens." University of Groningen.

Kavaratzis, M., \& Ashworth, G. J. (2005). City branding : An effective assertion of identity or a transitory marketing trick. Tijdschrift voor Economische enSociale Geografie.

Larasati, D. (2016). Potensi wisata dalam pembentukan city branding Kota Pekanbaru. Jurnal komunikasi, 10(2).

Luthfi, A., \& Widyaningrat, A. I. (2013). Konsep 
city branding sebuah pendekatan "the city brand hexagon " pada pembentukan (hal. 315-323). Diambil dari https://jurnal. unej.ac.id/index.php/prosiding/article/ view/9178/6144

Nuryanti, W. (1996). Heritage and enviorment management: the international perspective. Gadjah Mada University.

Peel, D., \& Lloyd, G. (2008). New communicative challenges: dundee, place branding, and the reconstruction of city image" in town planning review. JSTOR, $79(5)$.

Pfefferkorn, J. W. (2005). The branding of cities. exploring city branding and the importance of brand image. Graduate School of Syracuse.

Putri, F. A., Sumartias, S., \& Sjoraida, D. F. (2018). Proses rebranding mal grand
Indonesia oleh departemen marketing communication PT grand Indonesia. PRofesi Humas: Jurnal Ilmiah Ilmu Hubungan Masyarakat, 2(2). Diambil dari http:/jurnal.unpad.ac.id/profesi-humas/ article/view/9063/7833

Scott, A. J. (2006). Creative cities: conceptual issues and policy questions. Journal of Urban, 28(1).

Shaw, G. W. (1997). Critical issues in toursm: a geograpical perspective. Oxford: Blackwell.

Yuli, A. (2011). City branding sebagai strategi pengembangan pariwisata ditinjau dari aspek hukum merek (studi kasus city branding daerah istimewah Yogyakarta sebagai daerah tujuan wisata unggulan di Indonsia). Jurnal Ilmiah Ilmu Hukum QISTI, 5(1). 